confirm that babies dying from sudden infant death syndrome have increased alveolar instability as a result of surfactant abnormalities.

\footnotetext{
References

${ }^{1}$ Morley CJ, Hill CM, Brown BD, Barson AJ, David JA. Surfactant abnormalities in babies dying from sudden infant death syndrome. Lancet 1982;i:1320-3.

2 Fagan DG. Developmental and pathological studies of the structure and function of the lung in children. (Thesis). Cambridge: Cambridge University, 1973.

${ }^{3}$ Gribetz I, Frank WR, Avery ME. Static volume-pressure relationships of excised lungs of infants with hyaline membrane disease, newborn and stillborn infants. $J$ Clin Invest 1959;38: 2168.
}

${ }^{4}$ Fagan DG. Postmortem studies of the semistatic volumepressure characteristics of infants' lungs. Thorax 1976;31: 534-43.

5 Emery JL. Unexpected death in infancy. In: Hull D, ed. Recent advances in paediatrics - 5. Edinburgh: Churchill Livingstone, 1976:203-20.

6 James DK, Chiswick ML, Harkes A, Williams M, Hallworth J. Non-specificity of surfactant deficiency in neonatal respiratory disorders. Br Med J 1984;288:1635-7.

Correspondence to Professor A D Milner, Department of Child Health, University Hospital, Queen's Medical Centre, Nottingham NG7 2UH.

Received 17 January 1985

\title{
Night cough counts and diary card scores in asthma
}

\author{
L N J ARCHER AND H SIMPSON
}

Department of Child Health, Leicester University Medical School, Leicester Royal Infirmary

SUMMARY A tape recording system for recording night cough in asthmatics at home is described. Objective cough counts and half hour periods containing cough did not correlate with diary card scores awarded to eight children on seven nights each. Night cough diary scores may mislead in the assessment of symptom severity.

The severity of childhood asthma may be difficult to assess at outpatient clinic attendance. Reliance on history taking and examination alone may lead to an underestimate of disability caused by asthma. ${ }^{1}$ Symptom diary cards ${ }^{2}$ give subjective information on severity, while peak flow readings in the home are of value only in children old enough to cooperate properly in the use of peak flow meters. ${ }^{3}$ Cough counting with tape recorders has been performed for 20 years, ${ }^{4}$ but is rarely reported in the study of night cough in asthmatic children. ${ }^{5}$ We set out to compare recorded night cough counts with diary card scores of symptom severity in children with asthma.

\section{Patients and methods}

Eight asthmatic children aged 3 years and 6 months to 9 years and 8 months were each studied for seven nights, in seven cases consecutively. The children were on regular prophylactic treatment and their parents were already familiar with the use of symptom diary cards. Studies were carried out between acute exacerbations of the disease. Scores were awarded according to severity of night cough, thus: no cough 0 , little cough 1 , moderately bad cough 2 , and severe cough 3 . Scores were also awarded for severity of night-time wheeze, daytime wheeze, and daytime activity. A microphone placed near the child's head recorded cough during sleep with the recording level set to detect even the quietest cough. Sound recorded on channel I of the tape was also recorded on channel II one second later. The machine was switched on at the parents' bedtime and recorded continuously for six hours. Tapes were renewed daily without altering recording levels or the position of the microphone. They were later replayed through a compression unit triggered by the noise of a preset intensity on channel I so that the same noise was recorded from channel II onto tape 2. The compression unit was triggered by the quietest cough. The compressed tape (tape 2) was automatically switched off when signals from tape 1 ceased. The compression unit incorporated a time signal onto tape 2 every 30 minutes. The number of night coughs occurring during the original recording could then be counted by listening to the condensed tape with a time signal marking each half hour period.

\section{Results}

The Table summarises the results obtained from an analysis of 56 nights of recording in eight children. No child ever received a diary score of 3 for night cough and three children (cases 1, 2, and 4) always had a score of 0 . Thus, the full range of diary card scores was not available for each child to test whether night cough counts and diary card scores 
Table Diary scores and cough counts for 7 nights in each patient

\begin{tabular}{|c|c|c|c|c|c|c|c|c|c|}
\hline \multirow{2}{*}{$\begin{array}{l}\text { Diary night } \\
\text { cough score }\end{array}$} & \multicolumn{9}{|c|}{ Night cough counts in cases $1-8$ (median and (range)) } \\
\hline & & $l$ & 2 & 3 & 4 & 5 & 6 & 7 & 8 \\
\hline 0 & $\begin{array}{l}\text { TC } \\
\text { PC }\end{array}$ & $\begin{array}{l}5(0-16) \\
1(0-5)\end{array}$ & $\begin{array}{l}1(0-25) \\
1(0-2)\end{array}$ & $\begin{array}{l}(0-51) \\
(0-3)\end{array}$ & $\begin{array}{l}0(0-88) \\
0(0-4)\end{array}$ & $\begin{aligned} 25 & (6-44) \\
4 & (1-5)\end{aligned}$ & $\begin{array}{ll}5 & (2-13) \\
3 & (1-3)\end{array}$ & $\begin{array}{l}(32-47) \\
(3-6)\end{array}$ & $\begin{array}{l}\text { NA } \\
\text { NA }\end{array}$ \\
\hline 1 & $\begin{array}{l}\text { TC } \\
\text { PC }\end{array}$ & $\begin{array}{l}\text { NA } \\
\text { NA }\end{array}$ & $\begin{array}{l}\text { NA } \\
\text { NA }\end{array}$ & $\begin{array}{c}84(0-116) \\
3(0-11)\end{array}$ & $\begin{array}{l}\text { NA } \\
\text { NA }\end{array}$ & $\begin{array}{r}11 \\
2\end{array}$ & $\begin{array}{l}9(1-76) \\
3(0-4)\end{array}$ & $\begin{array}{c}33(0-37) \\
2(0-4)\end{array}$ & $\begin{aligned} 37 & (0-65) \\
4 & (0-5)\end{aligned}$ \\
\hline 2 & $\begin{array}{l}\text { TC } \\
\text { PC }\end{array}$ & $\begin{array}{l}\text { NA } \\
\text { NA }\end{array}$ & $\begin{array}{l}\text { NA } \\
\text { NA }\end{array}$ & $\begin{array}{l}\text { NA } \\
\text { NA }\end{array}$ & $\begin{array}{l}\text { NA } \\
\text { NA }\end{array}$ & $\begin{array}{r}16 \\
3\end{array}$ & $\begin{array}{l}\text { NA } \\
\text { NA }\end{array}$ & $\begin{array}{r}121 \\
8\end{array}$ & $\begin{array}{l}\text { NA } \\
\text { NA }\end{array}$ \\
\hline
\end{tabular}

$\mathrm{TC}=$ total cough count $\mathrm{PC}=$ half hour periods during which cough occurred.

If no median is given the corresponding diary score was given only twice: if a single figure, the score was given once.

NA (not applicable) indicates that a particular diary score was never awarded.

were related for the group as a whole. Night cough was present in each of seven children awarded a diary score of 0 . In the four children (cases 3, 5, 6, and 7) with varied diary card scores there was no obvious association between cough score and total cough counts or the number of half hour periods of recording during which cough occurred. In two children awarded day scores of 2 , one (case 5) had relatively little coughing and the other (case 3 ) the most of any child in the series. In some cases frequent (cases 3 and 5) or prolonged (case 3 and 8) bouts of coughing were not suspected by parents.

There was no correlation between night cough counts and diary card scores for night-time wheeze, daytime wheeze, daytime activity or for 24 hour diary scores calculated for the 24 hour period beginning with, and the period ending with, the night recording.

\section{Discussion}

We describe a simple, objective method of counting night cough in the home which although not practicable for use with large numbers of patients, is of value in obtaining information in selected cases. Using this system we have attempted to validate diary card scores in the assessment of severity of nocturnal cough in asthmatic children. The method had limitations, in particular only six hours of recording could be carried out at one time. This could have introduced bias in either direction, although the low diary card scores awarded in our study suggest that our patients did not have troublesome cough before their parents' bedtime when recording began. The system is now adapted so as to condense the tape at the time of recording thereby allowing a record to be made throughout the night. The use of diary cards provides a numerical expression of symptom severity often utilised in the statistical analysis of drug trials. This may lead to false conclusions as diary scores are clearly subjective with no 'weighting' for scores awarded for different manifestations of the disease in the same patient. Thus a score of 2 for night cough may not be comparable with a score of 2 given for interference with daytime activity. Our study confirms that with respect to night cough, diary card scores are unreliable and inconsistent in individual children providing further reason for caution in their interpretation. We conclude that night recording of cough can be readily carried out in the homes of children with asthma. Undue reliance on diary card scores which reflect parental impressions of symptom severity may give rise to errors affecting both the clinical management of individual patients and the interpretation of results of treatment trials in children with asthma.

We thank Mr A Colquhoun and Dr H Brash of the Department of Medicine, Royal Infirmary of Edinburgh for designing and making the recording and compression system and to Dr G Aucott (Department of Medical Physics, Leicester Royal Infirmary) for certain modifications to the system.

\section{References}

1 Speight ANP, Lee DA, Hey EN. Underdiagnosis and undertreatment of asthma in childhood. Br Med J 1983;286:1253-6.

2 Connolly N, Godfrey S. Assessment of the child with asthma. Journal of Asthma Research 1970;8:31-6.

${ }^{3}$ Chai H, Purcell K, Brady K, Falliers CJ. Therapeutic and investigational evaluation of asthmatic children. Journal of Allergy 1968;41:23-36.

${ }^{4}$ Woolf CR, Rosenberg A. Objective assessment of cough suppressants under clinical conditions using a tape recorder system. Thorax 1964;19:125-30.

5 Mascia AV. Evaluation of night coughing in asthmatic children. Journal of Asthma Research 1968;5:163-9.

Correspondence (no reprints available) to Professor H Simpson, University of Leicester School of Medicine, Department of Child Health, Leicester Royal Infirmary, PO Box 65, Leicester LE2 7LX.

Received 17 January 1985 